\title{
CLOTHING IMAGERY AS AN OFFENSIVE IMPLEMENT OF WARFARE AND HONOUR WITHIN PSALMS 108-110
}

\section{Lodewyk Sutton}

\author{
Research Fellow, Department of Old Testament Studies \\ University of Pretoria \\ E-mail: lodewyksutton@gmail.com
}

(Received 28/11/2016; accepted 05/05/2017)

DOI: https://doi.org/10.25159/1013-8471/3119

\begin{abstract}
Within the trilogy of Psalms 108-110 clothing imagery portrays an important part in establishing the development of honour within these three psalms. Within Book V of the Psalms this trilogy presents a theme of restoration after war (after the Babylonian exile). This is accomplished through a strong use of warfare images that are mainly demonstrated through the use of body and clothing (armour) imagery. This imagery indicates and conveys a strong message of restoration and of honour for the nation. Within war, clothing is considered as part of the armour and functions as part of a soldier's protection. Within Psalms 108-110 the clothing imagery takes on a different function as it becomes an offensive implement of warfare rather than a defensive implement. In this restorative function the clothing imagery strengthens the development of honour within Psalms 108-110.
\end{abstract}

\section{INTRODUCTION}

War imagery plays an important function within the Davidic trilogy of Psalms 108, 109, and 110; this is mainly due to its place within Book V of the book of Psalms. In the final redaction of the book of Psalms this trilogy was put together as a Davidic triptych (cf. Eybers 1978:32; Gawrisch 1981:8, 16; West 1981:440 footnote 4; Burden and Prinsloo 1987:13). Allen (2002:79-80) and Hossfeld and Zenger (2011:3) use the trilogy as evidence to indicate that within Book V this trilogy serves as a text that presents a nation that has returned from exile (the Babylonian exile) with a message of hope and restoration. Ironically, this is done mainly through the use of war imagery. In his explanation, Allen (2002:79-80) indicates that the Davidic superscriptions within these three psalms are used as an eschatological voice (representation ${ }^{1}$ ). The main

1 David is understood as a collective representative of the exiled nation. He becomes the metaphor of hope for salvation for the entire nation (Allen 2002:79-80). 
purpose of this Davidic eschatological voice is to be the salvation of Israel from her enemies in the future. Hossfeld and Zenger (2011:3) interpret David as the new David that helps to restore and show the dream of an Israel that has been restored, according to the model of the Davidic "foundational era". ${ }^{2}$ The question that arises is how is Israel restored? Within these three psalms different war imagery (mainly demonstrated through the use of body and clothing [armour] imagery), is used to indicate how the image of the king (the new David), as a group metaphor for Israel, ${ }^{3}$ is assisted and restored as the people of God. This becomes more evident when the imagery is understood from an ancient Near Eastern perspective of honour and shame within the context or theme of war. The question raised in this article is: how does the clothing imagery contribute in this prophetic description of restoration for Israel from the perspective of honour within the theme of war?

\section{METHODOLOGICAL CONSIDERATIONS}

Honour and shame are not strange concepts when it comes to the theme of war. War can serve as a way to either gain honour or to be shamed. To be sent into exile is to be shamed, while the victor of the war gains honour through the shaming of the defeated (Olyan 2011:20). Honour and shame in the context of war must be understood in the public domain as it is the honouring or shaming of a group (an individual as the king represents his people or group). To gain or lose honour was not enough; it must have been recognised and acknowledged in public (van Eck 1995:165-168; Pilch and Malina 2000:106-107). Therefore public displays of shaming the defeated by the victor were not a strange occurrence. To be defeated can happen when one has failed

2 The "new David" and "Davidic foundational era" indicates a time period of restoration for Israel that reflects the time during which Israel was a united kingdom that was ruled by King David and the kingdom flourished. It is a metaphor for restoring Israel to its former glory (Hossfeld and Zenger 2011:3).

3 On the possibly interpretation of a Davidic messianic king in Ps 110, the work of Goldingay (2008:292) can be consulted. In his interpretation, Goldingay (2008:292) indicates the arguments for and against a messianic interpretation. For the purpose of this article the new David is understood as part of the metaphor to indicate a period of restoration for Israel after a time of war and not as a specific future messianic character. 
(literally or even an emotion of failure) or is conquered by another (Ford 2000:45). Although physical shame was the most prominent way to shame a person, the conqueror often tormented the victim even further with mockery, gloating, and malicious glee. This verbal abuse was important to the ancient Near Eastern and Mediterranean person because "a word is dynamic, creating what it names" (Ford 2000:46). The defeated were often cursed by the victor. The curse was seen as a withdrawal of divine vitality and strength (Ford 2000:46; cf. Wright 2009:433-473). Israel's claim to honour was their special relationship with Yahweh. A national defeat was seen as God leaving the nation, bringing shame over Israel (Pilch and Malina 2000:106-112; cf. Malina 2001:27-57; DeSilva 2008:287-300; Crook 2009:591611). Van Eck (1995:166-168) explains this through the term "political shame". According to him this occurred when a person was captured by the enemy and shamed in public, for example by being tortured or removing the clothes of the person and making him or her walk naked. In this situation it is not only the person that is shamed but the entire group or nation that person is associated with. Honour was something that could be claimed or gained; therefore it was something that had to be protected (van Eck 1995:166-168).

In this article a socio-scientific analysis of the clothing imagery within Psalms 108-110 is made from the perspective of honour and the theme of war to answer the question: how does the clothing imagery contribute to this restoration for Israel? First, the clothing imagery used within Psalms 108-110 is identified. An intertextual analysis of each word provides a broader understanding of the use of the clothing imagery. Secondly, a social-scientific and contextual interpretation of clothes is made from the perspective of honour, taking into consideration the function of clothes within war. Thirdly, an analysis of the clothing imagery within Psalms 108-110 is made, indicating the function of the imagery from the perspective of honour and the theme of war. 


\section{IDENTIFYING THE CLOTHING IMAGERY WITHIN PSALMS 108-110}

In Psalms 108-110 clothing is an important part of the military imagery used; it also serves as a link between these psalms. Therefore it is necessary to investigate clothing in these psalms more closely. Armour and clothing played a major role in the strength of any soldier, specifically the helmet (the metaphor in Ps 108:9 implies that Ephraim becomes God's helmet, although helmet is not explicitly named), girdle, and shoes. What follows is an intertextual analysis of the clothing imagery that is used throughout Psalms 108-110; the analysis provides additional social background information on both the everyday use of these clothes and attire, and in war. ${ }^{4}$

\section{The sandal}

In Psalm 108:10, נַעַ can be translated as sandal (shoes). ${ }^{5}$ It represents straightforward footwear or shoes (Ringgren 1998:465). Twice in the Old Testament נַעַל is used as a verb (Ezek 16:10). A loincloth that has been belted, shoes and a staff (or sceptre) were seen as an indication that one was ready to set out for travel (Exod 12:11). Footwear (shoes) was worn by the nobility in particular. To exchange shoes was seen as part of confirming or closing a transaction, also a levirate marriage (Ruth 4:7). Since people in ancient times usually wore open sandals, washing the foot was a necessity and at the same time an honour shown to a guest (Gen 18:4; Judg 19:21; 1 Sam 25:41; Song 5:3; John 13:4-14; 1 Tim 5:10) (Shepherd 1962:308). When the Passover lamb was eaten, the Israelites had to put sandals on their feet as they needed to be ready to leave when the Pharaoh permitted it (Exod 12:11). If the shoes and

4 For the purpose of this article the clothing imagery represents shoes, clothes, and ornaments that are used to dress, mainly for war. It thus represents the entire range of garments used from head to toe. The imagery in Pss 108-110 concerning garments are all centred round male clothing, therefore in the discussion that follows the focal point will fall mainly on male garments.

5 Holladay (1988:240) translates נֵַַַל as sandal (tied with straps). Metaphorically it can be understood as "to take possession" or "in the refusal of a levirate marriage". Sivan and Levenston (1975:168) translate it as shoe or boot. Jastrow (1950b:920) translates it as shoe or lock (locking up). נַעַ is a primary noun and should be understood as a sandal with a simple sole made out of wood or leather that was bound to the foot with thongs (Gen 14:23; Isa 5:27). 
clothes did not wear out it was a sign of God's care (Deut 8:4) (Ringgren 1998:465466). In Isaiah 3:16 and 18 the ornaments on the women's feet is mentioned (Hastings 1963:303). Like donning shoes proclaims the renewal, renewed usage or once again taking up of the son's rights (Luke 15:22), taking off one's shoes and going barefoot mean misery and captivity (Isa 20:2-4), but also humility and worship in the presence of God (Exod 3:5; Josh 5:15) (Rienecker 1967:422; Ryken, et al. 1998:787).

The belt and shoes that are stained with blood was seen as a metaphor for battle garments (1 Kgs 2:5), or the willingness or readiness for battle (Isa 5:27). Throwing down one's shoes on something was seen as a sign of taking possession of that place or object. To throw down one's shoe could be seen as a sign of humiliation, domination, and subjugation, either in the sense of someone's slave to whom the one (a warrior in the context of Pss 60 and 108) flings his sandals to carry or to clean (Pss 60:10 and 108:10), or of a conqueror who puts his foot on a beaten foe as a sign of victory (Tate 1990:102; Ringgren 1998:466; cf. Grosheide 1955:451; Myers 1962a:213-214).

\section{The garments (garment, robe, tunic and cloak)}

Within Psalms 109 and 110 different words are used to describe the various garments.

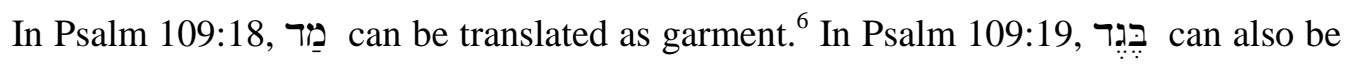
translated as garment, ${ }^{7}$ and in Psalm 109:29, מִִּ מִיל can be translated as robe. ${ }^{8}$

The Old Testament does not provide a detailed description of the clothes worn by people. Most information in this regard comes from art and statues of the ancient Near East. The first garments found in the Old Testament are those of Adam and Eve from fig leaves (Gen 3:7). What follows are garments made out of animal skins (Gen 3:21).

6 Holladay (1988:182) translates as measure or gauge. Jastrow (1950b:731) translates it as a priest's cloak.

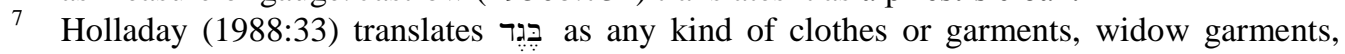
cultic garments, and the fullness of garments (his lap is full). Sivan and Levenston (1975:16) translate it as garment or dress. Jastrow (1950a:137) translates it as a web or garment. It can also be understood as if the garment functions as a web or is a web itself.

8 Holladay (1988:206) translates מִעיל as robe (for secular use or cultic use - garb of the high priest). Sivan and Levenston (1975:143) translate it as coat, jacket or overcoat. Jastrow (1950b:815) translates it as cloak, robe and high priest robe. 
The weaving of hair also became popular from an early period (Exod 26:7; 35:6); the sackcloth that was used by mourners was made from this type of cloth. Wool as a source for material also became popular at an early period (Gen 38:12). Wool was used mainly for the outer garments (מְעיל) (Lev 13:47; Deut 22:11). Another material used for clothing was flax, used to make linen garments. Silk was used only at a later period (exilic) (Ezek 16:10, 13). The colours used most were white, especially for cotton cloth, and purple (associated with a higher rank, the elite and royalty). Clothes that were embroidered and decorated were mainly used by royalty and the wealthy (Judg 5:30; Ps 45:13, 14; Ezek 16:13; Acts 12:21). ${ }^{9}$

In Israel, the making of clothes was primarily the task of women (housewives, 1 Sam 2:19; Prov 31:22). A definite distinction between male and female clothing could be observed due to the Mosaic law that forbids men to wear woman's clothing (Deut 22:5). The men's clothing consisted out of a number of pieces that made out their daily or formal (for cultic or war) dress. The tunic was the most simple of all the garments (Exod 28:4). It can be considered as an ordinary shirt or nightgown (in the modern sense). It covered the body only slightly, and therefore if someone did not wear anything else it could be considered that the person was naked (1 Sam 19:24; 2 Sam 6:20). It was also fastened around the loins with a girdle. This type of "garment" was worn by the priest as well (cf. Grosheide 1955:288-289; Unger 1957:276-279; De Wit 1962:323-326; Myers 1962b:869-871; Fensham and Oberholzer 1972:141146; Edwards 1992:232-238).

Another layer of clothing was the outer tunic. It was a looser and a longer sort of tunic. It reached down to the ankles, was open at the head, and had holes for the insertion of the arms. This was part of ordinary dress, worn by kings (1 Sam 24:4), prophets (1 Sam 28:14), nobles (Job 1:20), and youths (1 Sam 2:19). This is the garment referred to in Psalm 109:29. The outer tunic was regularly torn as a sign of mourning (Ezra 9:3; Job 1:20). The tunic and outer tunic were used as part of civilian and military dress (Ezek 23:15; Isa 5:27) (Douglas 2015:282). The mantle or cloak

9 Cf. Grosheide (1955:288-289); Unger (1957:276-279); de Wit (1962:323-326); Myers (1962b:869-871); Fensham and Oberholzer (1972:141-146); Edwards (1992:232-238). 
was a piece of cloth nearly a square, almost a sort of blanket. It was used to cover oneself, or in some instances it was used to carry things (Exod 12:34; $2 \mathrm{Kgs} \mathrm{4:39).} \mathrm{At}$ night the poor used it as a blanket. Breeches or drawers as a garment were worn under the tunic for a fuller covering. This was worn especially by priests, but does not seem to be generally used among the Hebrews. In some traditions the outer garment of special persons portrayed power or its loss. To take the garment was a sign of power taken or the defeat of an enemy (1 Sam 15:27). The cap or turban was a form of dress that belonged mainly to those of rank, such as the priest. People in general did not wear a cap but would in some circumstances wear a turban. These outer garments were used mainly by the high priest and some illustrious men (1 Sam 18:4; 2 Sam 6:14; Job 29:14; Ezek 26:16). ${ }^{10}$

Another cloak was sometimes used and worn by the king (Jonah 3:6) and prophets (1 Kgs 19:13, 19; 2 Kgs 2:13, 14). These robes were costly to make (Josh 7:21, 24) and therefore associated with the rich and powerful. Some linen garments (מֵ) were specially associated with the clothing of the priest and the high priest (Ps 109:18). The most general term for garments used by the king (Judg 8:26), high priest (Exod 28:2) and prisoners of war (2 Kgs 25:29; Jer 52:33) is בֶּנִ (over 200 times) (Ps 109:19). These garments were also used as a cover cloth for the Ark (Num 4:6-7) and for beds (1 Sam 19:13). ${ }^{11}$

In Psalm 110:3, הדז can be translated as ornament or attire. ${ }^{12}$ The translation of הדר Tדר remains in many circumstances uncertain; in such cases meaning is given to it by parallel expressions. הדרד Tר is used in relation to God (Ps 21:6) and the king (Ps 21:6). A person can be endowed with הדר (Isa 53:2). Other associations are nature (Lev 23:40); a city (Ezek 27:10); even a bull (Deut 33:17) can be distinguished by

${ }^{10}$ Cf. Grosheide (1955:288-289); Unger (1957:276-279); de Wit (1962:323-326); Myers (1962b:869-871); Fensham and Oberholzer (1972:141-146); Edwards (1992:232-238).

11 Cf. Grosheide (1955:288-289); Unger (1957:276-279); de Wit (1962:323-326); Myers (1962b:869-871); Fensham and Oberholzer (1972:141-146); Edwards (1992:232-238).

12 Holladay (1988:77) translates הדָד as the soul in its highest manifestation of power, ornament, attire, splendour (in nature; in human), God's glory or grandeur, and royal robes (of a king). Sivan and Levenston (1975:44) translate הדרד as splendour, glory and citrus fruits. Jastrow (1950a:335) translates דָדָר as adornment, crown, beauty and glory. Also associated with הדָר is terror. 
When הדרד is brought in relation to God, it signifies the royal dignity of a universal ruler. In this context הדָ דרדר becomes the "garment" which God puts on. In Psalm 110:3

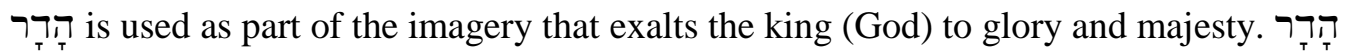
becomes an expression of God's power (Pss 29:4, 5; 110:3). הדרד is used to demonstrate God's power in nature and the reason to praise him and honour him (Pss 96:6; 104:1). הדרדר describes God's glorious deeds in history (Ps 111:3). In relation to an earthly king, it is used to describe his glory, or majesty. Psalm 110:3 is the only place where הדר in in used in the plural, therefore it could also indicate the glory of God and the king (in relation to Ps 110:1 where the king is sitting with Yahweh). In relation to a person הדר הדר is seen as the honour that is given to someone as a divine gift (Ps 8:6). הדרד was used as part of clothing imagery to describe the inner characteristics of a person (Prov 31:25). It becomes the glory, beauty and the special quality of a person. Lastly, הדר w was used to describe the fruit of goodly or ornament trees (trees such as the orange and citron, which were placed in gardens for ornament rather than use), that was gathered at the feast of Booths (Lev 23:40). When הדָ is used as a verb, it means to adorn or to honour and respect someone (Prov 20:29) (Warmuth 1978:335-341).

\section{The belt or girdle}

In Psalm 109:19, חגר can be translated as belt, girdle or to put on a belt/sword. ${ }^{13}$ The Hebrew word as a verb clearly represents more than just a belt or a buckle but represent various body-garments ${ }^{14}$ that are put around the body. חגר represents belts, waistbands or to be girdled the correct way for a ceremony or war (Kitchen 2015:413). These belts were usually ornate in nature and valuable. The belt was not only worn by men but also by women and was seen as fashionable (Prov 31:24; Dan 10:5). In war they were used to support the sword or dagger in its sheath (2 Sam 20:8; $1 \mathrm{Kgs} 2: 5$ ).

13 Holladay (1988:95) translates חגר as: to put on a belt, make ready for activity, buckle on, girded and to get ready. Sivan and Levenston (1975:82) translate חגר as gird (a sword) or to put on (a belt). Jastrow (1950a:424) translates חגר as to encircle or to gird.

14 This included the sash for priests (Exod 28:4) and dignitaries, the belt for a warrior's sword (2 Sam 20:8), and the waistband and girdle for everyday use (Kitchen 2015:413). 
The belt was used in war to show rank between soldiers (Isa 22:21); thus to remove someone's belt or girdle or to take it from him could symbolise taking that person's honour. In 1 Samuel 18:4 the girdle was also presented as part of a present and/or reward. At the work place it was used to tuck in the clothes. It was also used to carry money (to carry the wallet, Matt 10:9) (cf. Kitchen 1962:470-471; Fensham and Oberholzer 1972:144). ${ }^{15}$

\section{A SOCIO-SCIENTIFIC AND CONTEXTUAL INTERPRETATION The function of clothes within honour}

The garments of ancient Israelites for everyday wear were an assortment of clothes that consisted out of a linen tunic that was worn over some form of underwear, a woollen cloak with a belt or girdle around the chest, and sandals. On special occasions such as festivals, they wore different clothes (Gen 45:22; Judg 14:12-12), as well as for weddings (Matt 22:11-14). These festive clothes were known for their fine cloth, rich and vibrant colours and decorations of embroidery. ${ }^{16}$ Clothing was seen as valuable. An example of this can be seen in Mark 15:24, where the executioners at the cross of Jesus competed for his garments; also, when a person was robbed, his/her clothes were taken (Luke 10:30; 2 Tim 4:13). In a society where honour and shame are core values, clothes help to indicate one's role and status. ${ }^{17}$ Therefore, clothing cannot

15 Different words are used to express the term "girdle". Therefore, the following interpretations of girdle are also important: "to gird up the loins" meant that a person was ready for any type of service (Luke 12:35); "girdles of sackcloth" were worn as marks of sorrow and humiliation (Isa 3:24); it was seen as a symbol of strength, power and activity (Job 12:17; 30:11; Isa 23:10); righteousness and faithfulness are called the "girdle of the Messiah" (Isa 11:5) (Unger 1957:407).

16 In the story of the prodigal son (Luke 15) there is an example of this decorative clothing; he was dressed on his return with a robe, a ring for his finger and shoes for his feet.

17 The clothing worn "by the Hebrew people of biblical times was graceful, modest, and exceedingly significant. They were considered so much part of those who wore them that they not only told who and what they were, but were intended as external symbols of the individual's innermost feelings and deepest desires, and his or her moral urge to represent God aright. With certain kinds of cloth and with astonishingly vivid colors of white, purple, scarlet, blue, yellow, and black, they represented the state of their minds and emotions" (Douglas and Tenney 2011:372). 
be seen only as something that covered the body. Clothing helps to express the values of honour and shame. In a society of honour and shame, men and woman played different roles; thus, clothing expressed the different social functions men and woman performed (Deut 22:5; 1 Cor 11:14-15). Clothing did not only identify one's social status, but also one's nationality. One's trade could have been identified by the garments one wore; soldiers, merchants, peasants and priests wore different garments. Soldiers' garments were identified by a helmet, breastplate and greaves (Isa 59:17; Eph 6:14-17). When it came to status, the rich would always display this through their garments, by using fine linen, soft raiment, cotton from Egypt; silk from the orient and the colours purple, blue and scarlet ${ }^{18}$ (Exod 28:5-6; Isa 19:9; Jer 10:9; Ezek 16:10, 13; 1 Macc 4:23; Luke 7:25; 16:19; Rev 18:12). The king, in particular, would display his honour and status through his garments (Acts 12:21). But just as clothing showed honour and status, so it could show dishonour and shame. The poor were known for their "nakedness" (clothing is thus linked with honour, and nakedness, or the lack of proper clothing, with negative shame, see Matt 25:36) (Neyrey 2000:21-23).

By wearing appropriate headgear, a person would honour the head, as the honourable part of one's body. Therefore, ornaments like a crown show honour and status. By taking the enemy king's crown and wearing it, one shamed that king and showed one's dominance over him (2 Sam 12:30). Wearing the crown of two regions indicated a king's extended empire (1 Macc 11:13). There are examples of nobles and elders wearing crowns, indicating that they were being honoured and showing their status (Esth 8:15; Rev 4:4). The ornaments (jewellery) that women wore was an indication of their status (Esth 2:17; Ezek 6:11-12; 23:42). Thus, the loss of one's ornaments could mean that one's status was lowered (Luke 15:8), just as it meant that one could try to claim higher status by acquiring more clothes and ornaments (1 Pet 3:3). Religious status was indicated by garments (Matt 23:5) (Neyrey 2000:23). The high priest ministered in "eight pieces of raiment, and a common priest in four: in tunic, drawers, turban and girdle. To this the High Priest adds the breastplate, the

18 The colour white and spotlessness were seen as appropriate for heavenly encounters or heavenly liturgy (Mark 9:3; Eph 4:24; Rev 7:14) (Neyrey 2000:25). 
apron, the upper garment and the frontlet" (Neyrey 2000:23-24). While doing their normal priestly duties, priests wore linen breeches that were placed into the loins as to prevent exposing their genitalia (Exod 28:42); a checkered linen tunic that reached the feet; a linen girdle; a turban cap of wound linen bands and no shoes (Exod 3:5). In festive times, priestly garments became even more extravagant (Exod 28). Certain prophets would wear garments made out of animal skin rather than cloth to indicate their role on the margins of society (Zech 12:4; Mark 1:6; Heb 11:37-38). Prophets and/or those preaching repentance as well as those searching for repentance wore sackcloth (Matt 11:21; Rev 11:3, see Neyrey 2000:24). ${ }^{19}$

\section{The function of clothes within war}

War (whether political or holy) from the beginning to the end is understood as a battle situation with arms that happens between two groups, where lethal violence is used to force one to do the other's will (cf. Klassen 1992:867; Wigoder 2005:978). The language and imagery of war were employed by the biblical writers to show judgment, rule, power, honour and/or defeat (Joel 2:1-11; 3:9-12; Zeph 1:14-18; Rev 12:7-8; 17:14; 19:11) (cf. Mattingly 1985a:1118-1119; Klassen 1992:868; Römer 2013:7186). The methodology of war varied from nation to nation and also from period to period. Nevertheless, some aspects of warfare were universal (Mattingly 1985a:1119). Invariables or characteristics that are always present are: armies (two or more groups); strategy and method; weapons and armour. It is within the third invariable that clothing imagery needs to be evaluated. The weaponry can be classified into two

19 Garments must also be understood in relation to Israel's purity laws. To be whole is to be pure. Therefore, the high priest's clothes had to be made from a single piece of linen or wool, not a mixture (Deut 22:10, 11; Lev 19:19). The washing of clothes was mostly about purification rituals. Spatially, clothes helped to indicate moving into and from the space of God (Exod 19:10, 14; Lev 16:26; Num 19:7-10; 31:24). To move into the space of God one needed to be pure; therefore, one's clothes needed to be clean and pure. Laundering of clothes for hygienic reasons must be understood separately. Washing of garments was part of the purification rituals that needed to be performed when it came to the sick being declared healthy, and for those who touched a sick person or a dead human body (Lev $11: 40 ; 13: 6,34 ; 14: 8-9 ; 15: 3-8 ; 17: 15)$. In this circumstance the washing of the garments symbolised becoming clean or pure again, and is not about the concern of being sanitary (Neyrey 2000:24-25). 
groups: offensive weapons (arms) and defensive weapons (armour) (Mattingly 1985b:1123-1124). One's offensive weapons varied in nature and size, but all shared a common purpose: to be used in battle to attack or to assist in an attack. Some examples are: battle axe, sword and dagger, spear and javelin, bow and arrow, sling, engine and battering-ram, war chariot or horse chariot. Defensive weapons or armour were used in battle to protect a soldier against injury. ${ }^{20}$ These invariables or characteristics of war can be identified within warfare language and imagery (metaphors) as the following three groups of descriptive language: warriors and enemies (human or divine), experiences of warfare (as experienced by the individual or group, this includes the entire experience of the war from start to finish), and implements of warfare (weaponry and armour) (Kelle 2008:829). ${ }^{21}$ The descriptive language of the armour (clothing) is identified within the group "implements of warfare" and is then further understood as part of defensive implements of warfare.

The first function of defensive weapons or armour (warfare clothing) is to protect the soldier against injury (cf. Ryken et al. 1998:44: Seevers 2013:64). The shield (as the first layer of protection) served as the soldier's main form of defence. The shield was made out of various materials (usually wood and leather) and had various shapes and sizes. In Israel there were two varieties of shields. The first was the large shield that was supposed to protect the whole body (1 Kgs 10:16; Ps 5:12). The large shield was carried mainly by infantrymen. The second was the small shield, which was used mainly by archers ( 2 Chron 14:8). The helmet was used to protect the head. The helmets of soldiers differed from nation to nation (2 Chron 26:14), identifying a second function of the armour as a group or nation could be identified by the appearance of their armour. The body plate (coat of mail, breastplate or cuirass) was used to protect the chest. They were made from bronze for the leaders and leather for ordinary soldiers (Neh 4:16), identifying a third function of armour as it served as an indication of rank and status (Seevers 2013:65). These body plates also differed from

20 Cf. Grosheide (1955:467); Unger (1957:89-91, 189); Fensham and Oberholzer (1972:245246); Charley (1974:83-84); Wigoder (2005:982); Seevers (2013:57-64).

21 The language and imagery of the metaphor must be taken seriously as indicators of the social values of the ancient Near East and Mediterranean world. This is because they are the means of self-definition (Hobbs 1995:265). 
nation to nation in construction and appearance. The greaves were used to cover and protect the legs. They were used by most of the ancient nations and made mostly from brass (1 Sam 17:6). Other items of clothing, for example the tunic, outer tunic, the girdle (Isa 5:27), and sandal or boots (Isa 9:5), also served an important function in any soldier's attire, along with the rest of the garments (cf. Unger 1957:91-93; Fensham and Oberholzer 1972:246-248; Charley 1974:82-83; Seevers 2013:64-66; Douglas 2015:282).

All three functions of the soldier's armour (protection, denoting group or nation, indicating rank or status) contribute to the honour of a soldier. The armour "of a defeated warrior symbolizes shame for the vanquished and honour for the victor" (Ryken et al. 1998:43). A display of the defeated warrior's armour is to shame the warrior and his group or nation (1 Sam 31:10; Isa 45:1), especially the armour of the king or a high ranking officer. The armour becomes a symbol of victory, honour and domination for the victor and a symbol of defeat and shame for the defeated group or nation (cf. Ryken et al. 1998:43; Neyrey 2000:23-24).

\section{AN ANALYSIS OF PSALMS 108-110 \\ Psalm 108}

In Psalm 108 we find armies, enemies, and the hope of victory and the fear of defeat (Wilcock 2001:154). Psalm 108 must not only be understood as part of a Davidic trilogy but also as a petition for Yahweh's military saving intervention. ${ }^{22}$ In Psalm 108 the right hand (v. 7), the helmet (v. 9), the sceptre (v. 9), the washbasin (v. 10), the shoe (v. 10 - as part of the armour) and the trampling on the enemy (v. 14), all strongly show that a purposeful act is taking place. It shows Yahweh who will defeat the enemy (Botha 2010:580-581; Pilch and Malina 2000:98-99). Verses 8-10 contain

22 Psalm 108 is a new psalm, composed out of Ps 57:8-12 (prayer of petition with a strongly emphasized confession of trust) and Ps 60:7-14 (community lament). This new composition suggests that this psalm was composed as a result of specific historical circumstances or for a specific function, whether cultic or something else. Psalm 108 is mostly understood as a lament, but it is also a psalm of thanksgiving (Anderson 1981:758). 
the oracle, announcing the rescue of the people which consists of Yahweh's declaration that the territory of Israel and its surrounding countries belong to the area of his dominion. Such an oracle was given to a king before a battle, promising victory. Yahweh is presented as a soldier. The oracle (vv. 7-9) thus invokes the image of a great king who divides his territory after the victory, assigning status and function to each area. The area mentioned reminds one of the kingdom of David (Hossfeld and Zenger 2011:120). Since the psalm is composed in the post-exilic era, it represents a utopia in which Yahweh instead of a king reigns. It implies the unification of the divided kingdom of Israel, and that Yahweh will deal a final blow to the neighbours of Israel. The oracle (vv. 7-9) moves from north to south: the northern territories of Israel, then the central area, then the archenemies (Moab, Edom, Philistines). It can also be described as the areas of Jacob (Sukkoth and Shechem, Gen 33:17); JacobEsau (Israel-Edom), royal clothing or insignia (Ephraim and Judah), and dishonourable positions (Moab and Edom). Moab as a dishonourable position becomes a washbasin ${ }^{23}$ for washing the feet and Edom the storage space for shoes. ${ }^{24}$ The war clothing (helmet) ${ }^{25}$ and royal sceptre in verse 9 also confirms power and rule (Botha 2010:582). Ephraim and Judah become the places from which Yahweh's royal office is exercised. Ephraim that is to be the "helmet of his head" becomes imagery for the place from which he will fend off all enemy attacks. Judah will be the sceptre that shows rule and that will be used to strike down the enemy. This is the future plan for a new political dispensation when Yahweh will be king. Verses 11-14 describe how this can happen (Hossfeld and Zenger 2011:120), and are an indication of the current political situation where the restoration process is started but still needs to happen (this

23 Moab becomes a metaphor for the washbasin where the divine warrior washes himself after battle, a possible euphemism for the place which the warrior uses as a toilet after the battle.

24 In Ps 60:10 it was seen that Edom becomes a metaphor for the place where the divine warrior throws his battle shoes (Hossfeld and Zenger 2005:100). It can be seen as a sign of humiliation, domination and subjugation to throw down one's shoes (Isa 9:4), becoming a symbol of a conqueror who puts his foot on a beaten foe (becoming a "footstool") as a sign of victory (Tate 1990:102). Dahood (1968:80-81) translates the verb שלד in v. 10 as "plant", thereby finding a correlation to the imagery of the "feet" being placed on the neck of the enemy.

25 The helmet is also seen as being part of the protective clothing of the warrior. 
will happen in Pss 109 and 110) (Tucker 2014:70-71). In Psalm 108:10, the sandals or shoes become a symbol of dishonour and humiliation. They become offensive implements of warfare as they are used as a weapon to attack. The enemies will become Yahweh's "washbasin" (or even toilet) and resting place for his shoes (part of the armour). The imagery of the throwing down of the shoes associates with the imagery in verse 14 of being trampled on (act of humiliation and dishonour for the one being trampled on).

\section{Psalm 109}

Psalm 109 is mostly taken to be part of the "imprecatory psalms" due to its use of “curses” or evil words (Blaiklock 1977:77; Eybers 1978:28; Kidner 1979:388; Adams 1991). Others understand it as a judicial redress, in a religious court (Anderson 1981:758; Weiser 1982:690; Allen 2002:100; Harman 2011:785). Gerstenberger (2001:261; see also Weiser 1982:690) understands this psalm in terms of an individual who is defending himself against people who are accusing him of black magic and are planning to kill him. He regards the genre of this psalm as a "complaint of the individual" with a subgenre of being a "counter curse". As such, it is interpreted as a person making an appeal to God for help against his enemies (Kidner 1979:388-389; Wilcock 2010:156). One needs to take into account the strong appeal for the poor in this psalm, as it makes an appeal to God, who is the protector of the poor and needy (Hossfeld and Zenger 2011:138; see also Kirkpatrick 1903:652). In its final redacted location between Psalm 108 and Psalm 110, the Sitz im Leben of this psalm changes the "individual" focus to that of the group. In Psalm 108 and Psalm 109, the "foreign policy" of the king (or the new king, the revived David) concerning military action is seen clearly (cf. Hossfeld and Zenger 2011:132; Tucker 2014:75-76). The actual battle (whether physical or metaphorical) has started. Tucker (2014:72-78) indicates that within Ps 109 (as within Ps 108), vocabulary is used to support political connotations (the political powers or rather the "foes" that the psalmist wishes to be delivered from, and who threatens the existence of the nation) and that the psalmist states that the enemy "wages war" (לחם) against him (Ps 109:3). 
The one praying makes a summary of the actions of his enemies in verses 4-5. The psalmist here is not vindictive (Waltke 2007:879). He leaves the judgment and outcome to his only hope, an appeal to Yahweh that is the God of justice (Hossfeld and Zenger 2011:132). In verses 1-5 and also in verses 21-31 it seems that the person praying is confronted with a group of enemies (war language and imagery). The destructive desires of verses 6-19 are expressed to a single person; this can be explained by understanding that these verses are directed to an individual (the king that is, the representative of his nation). In verses 1-5 and verses $21-31$ the individual cries out towards the enemies, and in verses 6-19 the enemies cry out against the individual (Zenger 1996:60). The lament, as in the case of most lament psalms in the book of Psalms (Pss 3:3; 10:4, 6, 11, 13; 12:5; 13:5; 14:1), provides the actual words of the enemies. The reason why the petitioner does this is to give an especially vivid or clear picture of the enemies' hubris and brutality (Zenger 1996:60).

In Psalm 109 curses are one of the predominant forms of attack (Tucker 2014:7677). Although physical shame was the most prominent way to shame a person, to torment the victim even further with mockery, gloating, and malicious glee was common. These words of the opponents are literally words that are waging a war of destruction (honour and shame) against the petitioner (the king). In Psalm 109 the curses are used to torment and shame the king; therefore, help and assistance was needed in the battle. This help and assistance was given by Yahweh. ${ }^{26}$ In verses 16-18 the opponents' "fictional quotation" presents their accusations of guilt and also the charges made against the petitioner. This becomes the reason for destruction as described in verses 6-7. The accusation made against the petitioner is made in context of his work (spoken of in v. 8). The "charge" is: a misuse of office and a neglect of the poor (resulting in the poor's suffering and probable death). The charge is thus twofold. Firstly the petitioner did not live by the law of Yahweh, and secondly, he did not do his official duties (to take care of the poor and needy). Verses 17-18 make the argument of the accusers even stronger when "a theological antithesis between cursing

26 Brueggemann (2007:66) is convinced that one of the purposes of this psalm is to be cathartic, that the psalm serves as a therapeutic method to unload emotional distress. 
and blessing as well as by the use of heavy comparative imagery" is used (Hossfeld and Zenger 2011:134). The purpose is to show that the petitioner even enjoyed doing these evil deeds; it became part of his way of life (Hossfeld and Zenger 2011:133134). The cloak (garment) has a negative meaning of dishonour, as it is used to shame the petitioner (his armour is used to shame him). The (false) accusations made against the petitioner in verse 19 shows that the desired result is the destruction and annihilation of the petitioner. They call upon a (metaphorical) destruction that shows "cause and effect" (his destructive actions [charge against him] causes his shame that is a metaphorical death). The curse must weigh heavily on him; like his clothes it should bind him, that he himself will be the cause of his destruction (Hossfeld and Zenger 2011:134). It is war language and imagery that is used; the garments (cloak and girdle or belt ${ }^{27}$ becomes part of the destructive imagery, bringing dishonour. The garments become offensive implements of warfare, as they become part of the weapons that is used by the enemies to destroy the petitioner. The curse (the offensive weapon) became a garment (vv. 18-19). The garments did not form part of his armour to protect him, it was given to him like a sword gutting at him to destroy him even further.

Verse 20 develops into a kind of colophon or rather a subtitle to verses 6-19. It becomes a summary of the opponents' speech and a transition to the emphatic cry of the devout person for Yahweh's help (Zenger 1996:60). Verses 21-25 develop into the central plea for Yahweh's intervention on behalf of the one praying (Hossfeld and Zenger 2011:134). The feeling and desire for vengeance on the enemies is expressed in verses 28 and 29, although this expression of vengeance is gentler than the curses collected in verses 6-19. It would seem that his aim is to bring the enemies into dishonour on account of the dishonour they caused him (Zenger 1996:59). The petitioner knows that Yahweh's power renders the enemy curses, which have (cf. v. 19) been made towards him, completely futile. In fact it is such a futile process that the curses are turned into blessing, restoring his hope and giving him joy in his restoration before God (Hossfeld and Zenger 2011:135). Verse 29 is another

27 Part of the warrior's battle garments. 
summary; this time the petitioner expresses his retaliation for his enemies' punishment. He uses their own words (fictional words) in verse 25, but does not express the same outcome as they wished upon him. Instead the petitioner's honour should be restored in the public eye. The enemy's honour must be taken away as to show that the justice of Yahweh has prevailed (Hossfeld and Zenger 2011:135-136). In a society built upon honour and shame, the restoring of his honour is more important than a curse upon his enemies. The public shaming of their dishonour would be enough. The garments (clothing imagery, v. 29) become their dishonour now, a symbol of the restored honour of the one praying the psalm. In the same way as in verses 18 and 19 the clothes become a weapon that is used to destroy the enemies (it is not clothing or armour they already wore, it was given to them to put on). The clothing imagery is not that of protective or defensive armour, but that of an offensive weapon that is used to attack the enemy.

\section{Psalm 110}

Psalm 110 is mostly understood as a "royal psalm" ${ }^{28}$ It uses war imagery to show the enthronement of the new king as the "throne companion" and priest of and also with Yahweh. ${ }^{29}$ First, in Psalm 110:1 the lord (or king) who shares a throne with Yahweh and sits at the right hand or right side of Yahweh, shares in a specific sort of honour

28 Psalm 110 is on an exegetical level one of the most difficult psalms in the Old Testament. This is mostly due to its text-critical problems, especially in v. 3. Taking this into consideration it is clear that this psalm has been interpreted and reinterpreted through the ages, making this psalm in all probability one of the oldest psalms in the Old Testament. It is therefore according to some scholars even probable that in this process of reinterpretation some of the verses went missing or were changed and that it would explain why this psalm is so difficult to understand, or to see it as one complete textual entity (Anderson 1981:767; see also Oesterley 1939:461). For a further discussion on the royal psalms and their development, see Gunkel (1998:99-120) and de Bruyn (2009:68-79).

As part of the royal psalms, de Bruyn (2009:217) associates Ps 110 with the religious cultic practises of Jerusalem, and as part of the Judean Zion-theology. The psalm is also classified by many as a victory song, specifically a Jewish-Hellenistic victory song (Dahood 1970:112; Gunkel 1998:237-240; Hossfeld and Zenger 2011:144-145). Zenger (Hossfeld and Zenger 2011:145) sees the psalm as two divine speeches, with a common theme of subjection or defeat of the king's enemies by Yahweh and Yahweh's election of the king as his "throne companion". 
(also seen in Psalm 45:9) (Blaiklock 1977:79). ${ }^{30}$ There is a specific kind of authority (higher status) that goes along with this honour. It is to share in the honour of the king or in Psalm 110:1, in the honour of Yahweh. The king was the representative of Yahweh in the world, and now he sits with Yahweh on the throne. Within the trilogy of Psalms 108-110, Psalms 108 and 110 becomes the frame for the struggle against the enemies. The two "framing psalms $(108 ; 110)$ illustrate this most clearly in their depiction of Israel's struggle against hostile nations. In both instances, however, a divine oracle is spoken, assuring the audience that Yahweh has delivered the restored community from political powers that threaten their existence and will continue to do so" (Tucker 2014:68 cf. Brueggemann and Bellinger 2014:479-481). The garments in verse 3 become a metaphor for this restoration, as the "holy clothes" restores the honour (renewed honour) of the king's army. The garments or armour functions as a demonstration of this restored honour, the status and rank of the army. The garments become a further demonstration of the rule and power of the king in this process of restoration after war. Psalm 110 becomes a victory celebration after war and the fulfilment of the petition made in Psalm 108. Psalm 110 does not only become an expression of honour for Yahweh, but renewed honour for the king and his people.

Within verse 3 the birth imagery (מרושח - from the womb of Dawn) that is used to depict an enthronement scene is that of a new time period for the king. The verse implies a gift of renewal that is promised to the king within the imagery of the womb of the dawn. According to Hossfeld and Zenger (2008:195-215), in verse 3

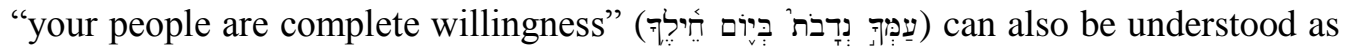
military personal, if one interprets this verse in the context of Psalms 108-110 and also Judges 5:2-9. This imagery is linked to Psalm 108:1 and 4 to illustrate that the day the king was born also became the day when his power (חיריל) and military strength were established. The soldiers and their "holy clothes" strengthen this message at the throne scene when the garments (cf. 2 Chron 20:21) become a display of honour and

30 Wyatt (2001:207) argues that the king who shares the throne of Yahweh must be understood in the sense that this king has now received godly status. He uses this argument to support Heb 1:13. 
an even higher status. ${ }^{31}$ The image of the king (representing the group) in Psalm 110 (nation and soldiers) is restored within this imagery. In this psalm the enemies are stripped of their honour, and Yahweh is shown to be the true divine king who has all the power and honour. In this process also, the king's (and his people's) honour is also restored, and he receives a status of renewed honour.

\section{CONCLUSION}

Psalms $108-110$ is a trilogy that contributes to the restoration process of Israel after the Babylonian exile, by restoring their honour and identity as the people of Yahweh. There is much imagery within the trilogy that contributes to this function of restoration. The warfare clothing imagery within Psalms 108-110 takes on a different role as it is used as an offensive implement of warfare rather than the more prominent defensive role. As such, the clothing imagery is used as a weapon to bring dishonour or shame over the defeated enemies and present honour or rather restored honour to the king as the representative of his people. The implication is that the clothing imagery within Psalms 108-110 must be understood as restorative imagery for a nation after a destructive war. The imagery in the trilogy illustrates the different stages of the war that contributes to this process of restoration of honour. The process of restoration starts in Psalm 108 as a solace that honour will be restored (announcement of war) and continuous to Psalm 109 where restoration starts and the battle for honour unfolds (the battle) that leads to the final restoration in Psalm 110 with a demonstration of renewed honour and status (victory).

31 In this regard see Pss 29:2 and 96:9, where the motive of "holy clothes" features in the context of the throne of Yahweh. 


\section{BIBLIOGRAPHY}

Achtemeier, P J (ed.) 1985a. Harper's Bible dictionary. San Francisco Harper \& Row. 1985b. Harper's Bible dictionary. San Francisco: Harper \& Row.

Adams, J E 1991. War psalms of the Prince of Peace. Lessons from the imprecatory psalms. New Jersey: Presbyterian and Reformed Publishing Company.

Allen, L C 2002. Psalms 101-150. Word Biblical Commentary. Nashville: Thomas Nelson Publishers.

Anderson, A A 1981. Psalms 73-150. The New Century Bible Commentary. Grand Rapids: WM. B. Eerdmans Publ. Co.

Blaiklock, E M 1977. Psalms for worship. Psalms 73-150. London: Scripture Union.

Botha, P J 2010. Psalm 108 and the quest for closure to the exile, Old Testament Essays 23/3:574-596.

Botterweck, G J, Ringgren, H and Fabry H-J (eds) 1998. Theological dictionary of the Old Testament. Volume 9. Grand Rapids: William. B. Eerdmans Publishing Company.

Botterweck, G J and Ringgren, H (eds) 1978. Theological dictionary of the Old Testament.

Grand Rapids: William B. Eerdmans Publishing Company.

Brueggemann, W 2007. Praying the Psalms. Engaging Scripture and the life of the Spirit.

Second edition. Eugene: Cascade Books.

Brueggemann, W and Bellinger, W H 2014. Psalms. New Cambridge Bible Commentary. New York: Cambridge University Press.

Burden, J J and Prinsloo, W S (eds) 1987. Twee-gesprek met God. Die literatuur van die Ou

Testament. Deel 3. Kaapstad: Tafelberg-Uitgewers.

Buttrick, G A (ed.) 1962a. The interpreter's dictionary of the Bible. Volume 4. New York: Abingdon Press.

1962b. The interpreter's dictionary of the Bible. Volume 1. New York: Abingdon Press.

Charley, J W 1974. Armour and weapons, in Douglas 1974:82-84.

Crook, Z 2009. Honor, shame, and social status revisited, Journal of Biblical Literature 128/3:591-611.

Dahood, M 1968. Psalms II, 50-100. The Anchor Bible. New Haven: Yale University Press. 1970 (2011). Psalms III, 101-150. The Anchor Bible. New Haven: Yale University Press.

De Bruyn, J J 2009. Die Christologie van die Psalter binne die konteks van die

Koningspsalms? ' $n$ Praktiese toespitsing op Psalm 45 en 110. Doktorale Tesis,

Departement Ou Testament. Pretoria: Universiteit van Pretoria.

De Wit, C 1962. Dress, in Douglas 1962:323-326.

DeSilva, D A 2008. Honor and shame, in Longman III and Enns 2008:287-300

Douglas, J D (ed.) 1962. The new Bible dictionary. London: Inter-Varsity Press. 1974. The new Bible dictionary. London: Inter-Varsity Press.

2015. Dress, in Marshall, Millard, Packer and Wiseman 2015:282-283.

Douglas, J D and Tenney, M C 2011. Zondervan illustrated Bible dictionary. Grand Rapids: Zondervan.

Edwards, D R 1992a. Dress and ornamentation, in Freedman 1992a:232-238.

Esler, P F (ed.) 1995. Modelling early Christianity. Social-scientific studies of the New Testament in its context. London: Routledge.

Eybers, I H 1978. Gods woord in mensetaal. Deel III. Die ontstaan, inhoud en boodskap van die "Geskrifte" in die Hebreeuse kanon. Durban: Butterworths. 
Fensham, F C and Oberholzer, J P 1972. Bybelse aardrykskunde, oudheidkunde en opgrawings. Pretoria: Interkerklike Uitgewerstrust.

Ford, J M 2000. Defeat, in Pilch and Malina 2000:45-48.

Freedman, D N (ed.) 1992a. The anchor Bible dictionary. Volume 2. New York: Doubleday. 1992b. The anchor Bible dictionary. Volume 6 (Si-Z). New York: Doubleday.

Gawrisch, W R 1981. Introduction to the Psalms. Available:

http://www.wlsessays.net/files/GawrischPsalms.pdf [Accessed 2014/03/28].

Gerstenberger, E S 2001. Psalms Part 2 and Lamentations. Grand Rapids: William B.

Eerdmans Publishing Company.

Goldingay, J 2008. Psalms. Volume 3: Psalms 90-150. Baker Commentary on the Old

Testament Wisdom and Psalms. Grand Rapids: Baker Academic.

Grosheide, F W 1955. Bybelse ensiklopedie. Kaapstad: Verenigde Protestantse Uitgewers.

Gunkel, H 1998 (1933). An introduction to the Psalms. Macon: Mercer University Press.

Harman, A 2011. Psalms. A Mentor commentary. Volume 2: Psalms 73-150. Ross-Shire: Mentor.

Hastings, J (ed.) 1963. Dictionary of the Bible. New York: Charles Scribner's Sons.

Hobbs, R 1995. The language of warfare in the New Testament, in Esler 1995:259-273.

Holladay, W L 1988. A concise Hebrew and Aramaic lexicon of the Old Testament. Grand

Rapids: William B. Eerdmans Publishing Company.

Hossfeld, F L and Zenger, E 2005. Psalms 2. Hermeneia. Minneapolis: Fortress Press. 2008. Psalmen 101-150. Herders Theologischer Kommentar zum Alten

Testament. Freiburg, Basel, Wien: Herder.

2011. Psalm 3. Hermeneia. Minneapolis: Fortress Press.

Jastrow, M 1950a. Dictionary of Talmud Babli, Yerushalmi, Midrashic literature and

Targumim. Volume I. New York: Pardes Publishing House, Inc.

1950b. Dictionary of Talmud Babli, Yerushalmi, Midrashic literature and Targumim.

Volume II. New York: Pardes Publishing House, Inc.

Kelle, B E 2008. Warfare imagery, in Longman III and Enns 2008:829-835.

Kidner, D 1979. Psalms 73-150. The Tyndale Old Testament Commentaries. London: InterVarsity Press.

Kirkpatrick, A F 1903. The book of Psalms. The Cambridge Bible for Schools and Colleges. Cambridge: University Press.

Kitchen, K A 1962. Girdle, in Douglas 1962:470-471.

2015. Girdle, in Marshall, Millard, Packer and Wiseman 2015:413.

Klassen, W 1992b. War in the New Testament, in Freedman 1992b:867-875.

Longman III, T and Enns P (eds) 2008. Dictionary of the Old Testament. Wisdom, poetry \& writings. Nottingham: Inter-Varsity Press.

Malina, B J 2001. The New Testament world. Insights from cultural anthropology.

Kentucky: WJK Westminster John Knox Press.

Marshall, I H, Millard, A R, Packer, J I and Wiseman, D J 2015. New Bible dictionary. Third edition. Downers Grove, Illinois: IVP Academic.

Mattingly, G L 1985a. War, in Achtemeier 1985a:1118-1119.

1985b. Weapons, in Achtemeier 1985b:1123-1124.

Myers, J M 1962a. Sandals and shoes, in Buttrick 1962a:213-214.

1962b. Dress and ornaments, in Buttrick 1962b:869-871.

Neyrey, J H 2000. Clothing, in Pilch and Malina 2000:21-27.

Oesterley, W O E 1939. The Psalms. Translated with text-critical and exegetical notes.

Volume II. London: Society for Promoting Christian Knowledge. 
Olyan, S M 2011. Social inequality in the world of the text. The significance of ritual and social distinctions in the Hebrew Bible. Oakville: Vandenhoeck \& Ruprecht.

Pilch, J J and Malina, J M (eds) 2000. Handbook of biblical social values. Massachusetts: Hendrikson Publishers, Inc.

Rienecker, F 1967. Lexikon zur Bibel. Wuppertal: R. Brockhaus Verlag.

Ringgren, H 1998. נֵַַַ in Botterweck, Ringgren and Fabry 1998:465-467.

Römer, T 2013. Dark God. Cruelty, sex, and violence in the Old Testament. New York: Paulist Press.

Ryken, L, Wilhoit J C, and Longmann III, T 1998. Dictionary of biblical imagery. Downers Grove, Illinois: IVP Academic.

Seevers, B 2013. Warfare in the Old Testament. Grand Rapids: Kregel Academic.

Shepherd, M H 1962. Foot washing, in Buttrick 1962a:308.

Sivan, R and Levenston, E A 1975. The new Bantam-Megiddo Hebrew and English dictionary. New York: Bantam Books.

Tate, M E 1990. Psalms 51-100. Word Biblical Commentary. Colombia: Nelson.

Tucker, W D 2014. Constructing and deconstructing power in Psalms 108-110. Ancient Israel and its Literature 19. Atlanta: Society of Biblical Literature.

Unger, M F 1957. Unger's Bible dictionary. Chicago: Moody Press.

Van Eck, E 1995. Galilee and Jerusalem in Mark's story of Jesus, Hervormde Teologiese Studies. Supplementum 7. Pretoria: University of Pretoria.

Waltke, B K 2007. An Old Testament theology. Grand Rapids: Zondervan.

Warmuth, G 1978. הדר , in Botterweck and Ringgren 1978:335-341.

Weiser, A 1982. The Psalms. The Old Testament Library. London: SCM Press.

West, J K 1981. Introduction to the Old Testament. Second edition. London: Collier Macmillan Publishers.

Wigoder, G (ed) 2005. The illustrated dictionary and concordance of the Bible. New York: Sterling Publishing.

Wilcock, M 2001. The message of Psalms 1-72. The Bible Speaks Today. Nottingham: InterVarsity Press. 2010. The message of Psalms 73-150. The Bible Speaks Today. Nottingham: InterVarsity Press.

Wright, J L 2009. The commemoration of defeat and the formation of a nation in the Hebrew Bible, Prooftexts 29:433-473.

Wyatt, N 2001. Space and time in the religious life of the Near East. Sheffield: Sheffield Academic Press.

Zenger, E 1996. A God of vengeance? Understanding the psalms of divine wrath. Kentucky: Westminster John Knox Press. 